\title{
The association of asthma-obesity in the context of SARS-CoV-2 - the general practitioner's point of view
}

\author{
Asocierea astm-obezitate în contextul infecţiei cu SARS-CoV-2 - \\ punctul de vedere al medicului de familie
}

\author{
Mihaela Adela lancu ${ }^{1,2}$, Irina Eremia ${ }^{1,3}$, Adriana Ticără ${ }^{1,2}$, \\ Camelia Cristina Diaconu ${ }^{1,4}$, Dumitru Matei ${ }^{1,5}$ \\ ${ }^{1}$ Universitatea de Medicină și Farmacie „Carol Davila“, București, România \\ ${ }^{2}$ Cabinet medical individual, București, România \\ ${ }^{3}$ Spitalul Universitar de Urgență, București, România \\ ${ }^{4}$ Spitalul Clinic de Urgență, București, România \\ 5Institutul Național pentru Sănătatea Mamei și Copilului „Alessandrescu-Rusescu“, București, România
}

\begin{abstract}
Obesity represents a risk factor concerning the severity and frequency of asthma attacks. A number of obesity-related factors contribute to the increased risk and severity of asthma. The relationship between obesity and asthma derives from a complex interaction of biological, physiological and environmental factors. Some of these factors are causes for increased the severity of SARS-CoV-2 infection forms. Encouraging weight loss strategies, through a change in lifestyle, a balanced diet, as well as combating a sedentary lifestyle, is an essential stage of asthma management within the family doctor's field. Further studies are needed to further develop the strategy regarding the comorbidity of obesity - asthm - -SARS-CoV-2 infection.
\end{abstract}

Keywords: obesity, asthma, SARS-CoV-2, general practitioner

\section{REZUMAT}

Obezitatea este un factor de risc pentru severitatea și frecvența crizelor de astm. O serie de factori legați de obezitate contribuie la creșterea riscului și severități astmului. Relația dintre obezitate și astm derivă dintr-o interacțiune complexă de factori biologici, fiziologici și de mediu. Unii dintre acești factori sunt implicați în creșterea severității formelor de infecție cu SARS-CoV-2. Încurajarea strategiilor de scădere ponderală, prin modificarea stilului de viață, o dietă echilibrată şi combaterea sedentarismului, este o etapă esențială a managementului astmului în practica medicului de familie. Este nevoie de studii suplimentare pentru a completa strategia de abordare a asocierii obezitate - astm - infecție SARS-CoV-2.

Cuvinte cheie: obezitate, astm, SARS-CoV-2, medic de familie

\section{IMPORTANT!A PROBLEMEI}

Obezitatea este un factor de risc pentru severitatea și frecvența crizelor de astm, atât la copil, cât și la adult. Relația dintre obezitate și astm derivă dintr-o interacțiune complexă de factori biologici, fiziologici și de mediu [1]. Creșterea paralelă a prevalenței astmului și obezității a determinat creșterea interesului în studiul relației dintre aceste două afecțiuni [2]. Astmul la pacienții care asociază obezitate este adesea sever și dificil de controlat, cu răspuns redus la terapia farmacologică și scăderea calităţii vieții [1]. 


\section{EPIDEMIOLOGIE}

În ultimele decenii, obezitatea și astmul prezintă în paralel o creștere a prevalenței. Prevalența astmului este crescută la pacienții diagnosticați cu obezitate, în special la sexul feminin [1]. Se estimează că peste 339 de milioane de oameni suferă de astm la nivel global [3]. Potrivit Organizației Mondiale a Sănătății (2016), există aproximativ 2 miliarde de adulți cu exces ponderal [4]. În Statele Unite, prevalența astmului la femeile care au obezitate comparativ cu cele normoponderale este de $14,6 \%$, respectiv $7,9 \%$, în timp ce prevalența la bărbații care au obezitate, comparativ cu cei normoponderali, este de 7,1\% şi, respectiv, 6,1\% [5].

Dintre adulții cu astm sever, aproape $60 \%$ sunt obezi [1]. O prevalență crescută a astmului apare și la copiii cu obezitate; raportul de probabilitate ajustat de a avea astm este de 1,29 (CI 95\% 1,16-1,42) la copiii obezi comparativ cu copiii normoponderali [6]. În contextual epidemiologic actual, prezența obezității este factor de risc pentru formele severe de COVID-19, atât la copil, cât și la adult. Indicele de masă corporală între $25 \mathrm{~kg} / \mathrm{mp}$ și $30 \mathrm{~kg} /$ $\mathrm{mp}$, precum și formele moderate și severe de astm reprezintă posibili factori de agravare a severității infecției cu virusul SARS-CoV-2 [7].

\section{RELAȚIA OBEZITATE-ASTM}

Relația obezitate-astm a început să fie studiată după anii ' 80 [8].Cu cât indicele de masă corporală (IMC) este mai mare, cu atât este mai mare riscul de asociere cu astm. Riscul de apariție a astmului este crescut de 1,4 ori pentru adulții cu un IMC de $30,0-34,9 \mathrm{~kg} / \mathrm{m}^{2}$ [9]. Obezitatea poate fi un simplu marker al stilului de viață recent adoptat, din cauza excesului caloric și scăderii nivelului de exerciții fizice, dar obezitatea epidemică induce astm necontrolat și astm care nu se remite după pubertate, acest fapt fiind un fenomen îngrijorător la adolescenţi [8].

\section{SITUAȚII CLINICE}

Ca medici de familie, am observat, mai ales la adolescenți, faptul îngrijorător că obezitatea precede astmul, obezitatea fiind un factor de risc pentru dezvoltarea ulterioară a astmului, fiind responsabilă sau jucând un rol în generarea astmului sau agravarea acestuia [8].

Situațiile în care astmul precede obezitatea sugerează că astmul poate fi un factor de risc pentru dezvoltarea obezității prin evitarea efortului fizic ca determinant al apariției crizelor astmatice. Studiile au arătat că prezența astmului la vârsta de 3-4 ani dublează riscul de obezitate până la 8 ani [10].

\section{INTERRELAȚII POSIBILE. FACTORI POSIBILI IMPLICAȚI}

O serie de factori legați de obezitate contribuie la creșterea riscului și severității astmului la pacienții cu obezitate, dar mecanismul patogenic nu este cunoscut încă. Patogeneza astmului care se dezvoltă la un pacient obez diferă de mecanismul patogenic implicat în astmul complicat de obezitate [8]. Obezitatea și modificările metabolice asociate pot provoca hipereactivitate bronșică în prima situație, în timp ce acestea pot contribui la severitatea astmului și la controlul terapeutic în cea din urmă [8].

\section{Fenotipuri de obezitate asociate cu astm}

Se descriu două fenotipuri importante de obezitate asociată cu astm: astm complicat de obezitate şi astm precedat de obezitate.

Astmul complicat de obezitate se caracterizează prin astm alergic cu debut precoce (<12 ani), complicat ulterior cu exces ponderal. Acești copii au markeri crescuți ai inflamației, istoric de atopie, nivel ridicat de imunoglobulină serică, modificări fiziologice semnificative (obstrucție a căilor respiratorii și hiperreactivitate marcată, exacerbări frecvente cu severitate medie sau crescută). Excesul ponderal la acești pacienți este mai mare decât la cei cu boală cu debut ulterior obezității [11].

Astmul precedat de obezitate se caracterizează prin astm cu debut $\geq 12$ ani, inflamație redusă, mai frecvent întâlnit la pacienții de sex feminin [11]. Gradul de obstrucție a fluxului de aer și hiperreactivitatea sunt reduse și gradul de exces ponderal este mai puțin sever [12].

\section{Factori genetici}

Studiile efectuate pe gemeni monozigoți sugerează că $8 \%$ din componenta genetică a obezității se asociază cu astmul [13].

\section{Expuneri de mediu}

Studiile observaționale sugerează că expunerea la poluarea aerului și fumatul părinților sunt factori de risc independenți atât pentru dezvoltarea obezității, cât și a astmului la copii [14]. Se descriu factori suplimentari ce ar putea juca un rol în interacțiunea dintre fumatul activ și infecția cu SARS-CoV-2. Studiile publicate până în prezent 
descriu modificări structurale care apar în mod natural în variantele alelice ACE2 care interferă cu proteina SARS-CoV-2 spike [15]. Deși este posibil ca fumul de țigară să crească expresia receptorilor ACE2 la nivelul epiteliului bronșic, facilitând astfel intrarea virusului SARS-CoV-2, nu s-a dovedit existența unui risc mai mare de a dezvolta forme severe de COVID-19 [15].

\section{Dieta}

Dieta bogată în glucide sau acizi grași saturați sau săracă în antioxidanți sau fibre este asociată cu o creștere a severităţii astmului și a obezităţii $[16,17]$.

Dieta bogată în acizi grași saturați crește nivelul inflamaţiei mucoasei bronșice [17]. La nivel individual, în special în condițiile carantinei instituite în primăvara acestui an, mai ales ca medici de familie, trebuie să trimitem mesaje simple repetate, dar importante, pentru menținerea stilului de viață corect în timpul pandemiei COVID-19: exercitii fizice regulate și dietă echilibrată, caloric și nutritiv [18].

Nivelurile scăzute de micronutrienți, cum ar fi vitamina $\mathrm{D}$, pot contribui, de asemenea, la riscul de astm și de obezitate. Există în deșfășurare studii care s-au concentrat asupra rolului vitaminei $\mathrm{D}$, a formei active de vitamină $\mathrm{D}$, calcitriolul, și profilaxia formelor severe de COVID-19, în special la persoanele care prezintă deficit de vitamină D [19].

\section{INFLUENTTA OBEZITĂȚII ASUPRA FUNCTIIEI PULMONARE}

La pacienţii obezi, scad VEMS-ul, capacitatea vitală forțată (FVC), capacitatea pulmonară totală, capacitatea reziduală funcțională și volumul expirator de rezervă [8]. Restricția toracică asociată obezității este de obicei ușoară și este atribuită efectelor mecanice ale adipozității (excursiile diafragmatice și complianța toracică sunt reduse) [8]. Forța musculaturii respiratorii și capacitatea de efort pot fi compromise de obezitate (ineficiența musculaturii prin reducerea complianței peretelui toracic și operarea cu volume pulmonare mai mici), fapt dovedit prin reducerea presiunii inspiratorii maximale (versus normoponderali) [8].

Funcția cardiorespiratorie în repaus este păstrată, dar la efort este redusă, ca urmare a costurilor metabolice suplimentare mari, explicând asocierea dispneei în aceste condiții, cu dezechilibrul la nivel de mușchi respiratori creat între cererea adresată muşchilor respiratori și capacitatea lor de a genera tensiune, ceea ce duce la percepția de creștere a efortului respirator [8].

\section{MEDIATORI AI ȚESUTULUI ADIPOS}

Țesutul adipos la persoanele obeze eliberează mediatori proinflamatori: interleukina 6 (IL-6), asociată cu un control slab al astmului, factorul de necroză tumorală-alfa - asociat cu reacția inflamatorie din astm, leptina, care afectează căile respiratorii prin scăderea activității sistemului nervos parasimpatic $[1,8,20]$, în timp ce eliberarea de adipokine antiinflamatorii (adiponectina) este redusă [21].

Studiile referitoare la infecția cu SARS-CoV-2 arată că nivelurile de IL-6 la internarea în spital par a reprezenta un factor de prognostic negativ pentru evoluția spre boală severă și/sau mortalitate [22]. Prin urmare, studiile susțin ipoteza că vizarea furtunii de citokine indusă de SARS-CoV-2 prin utilizarea medicamentelor anti-IL-6 ar putea fi o opțiune terapeutică validă, asociață cu strategii de susținere, pentru îmbunătățirea rezultatelor la pacienții cu COVID-19 [22,23].

\section{FUNCTTIA CELULELOR IMUNE}

Asocierea obezitate - astm se caracterizează prin suprimarea funcției limfocitelor T-helper implicate în răspunsurile alergice [24]. De asemenea, s-a observat faptul că eozinofile din submucoasă sunt crescute la pacienții obezi cu astm față de pacienții normoponderali, cu observația că eozinofilele din spută și din sângele periferic nu cresc cu IMC [24].Pacienții cu COVID-19 care au prezentat leucocitoză au dezvoltat forme severe de boală, au fost mai susceptibili de a fi admişi la terapie intensivă, mai susceptibili la indicația de ventilație mecanică și au avut o mortalitate mai mare [23,25].

\section{EVALUAREA COMORBIDITĂTiILOR}

Pacientul cu obezitate și astm prezintă comorbidităţi ce pot afecta controlul astmului, dacă nu sunt monitorizate atent [8]. Medicul de familie trebuie să monitorizeze următoarele comorbidități:

- indromul de apnee în somn - sever sau netratat, poate agrava astmul, reduce scapacitatea funcțională și poate duce la hipertensiune pulmonară $[1,8]$.

- refluxul gastroesofagian - prezintă prevalență crescută la pacienții cu obezitate și astm [8].

- sindromul metabolic - IL-6 este crescută la pacienţii cu un control slab al astmului $[1,8,20]$

- depresia asociată bolii cronice, cu scăderea stimei de sine. 


\section{IMPLICATTIILE TERAPEUTICE ALE OBEZITĂȚII LA PACIENȚII CU ASTM}

Tratamentul astmului la pacienții obezi este în mare măsură similar cu pacienții nonobezi.

Tratamentul farmacologic din criză sau de fond este recomandat conform ghidurilor, nu există diferențe între pacienții cu astm asociat obezităţii și astm la pacientul normoponderal [8]. Etapa importantă în managementul astmului asociat obezităţii este reprezentată de intervențiile medicului de familie asupra stilului de viață, având ca scop scădere în greutate, o dietă echilibrată și un nivel optim de exerciții fizice

În general, studiile privind intervențiile de scădere în greutate arată îmbunătățiri în controlul astmului, calitatea vieții legate de astm și funcția pulmonară dacă se atinge un nivel optim de scădere în greutate (cel puțin 5\%) [8].

\section{VACCINAREA PACIENȚIILOR CU OBEZITATE ȘI ASTM}

În practica medicului de familie, un aspect important îl reprezintă vaccinarea, ca metodă de profilaxie primară. În cazul pacienţilor cu obezitate și astm, luăm în considerare indicația de vaccinare antigripală și antipneumococcică.

Pacienții cu obezitate prezintă un risc crescut de boală severă cauzată de gripă, iar administrarea anuală a vaccinului antigripal este recomandată tuturor pacienților obezi cu astm [26].

\section{BIBLIOGRAFIE}

1. Peters U, Dixon AE, Forno E. Obesity and asthma. J Allergy Clin Immunol. 2018;141(4):1169.

2. Mohanan S, Tapp H, McWilliams A, Dulin M. Obesity and asthma: Pathophysiology and implications for diagnosis and management in primary care. Exp Biol Med (Maywood). 2014;239(11):1531-1540.

3. https://www.who.int/news-room/fact-sheets/detail/asthma.

4. https://www.worldobesity.org/about/about-obesity/prevalence-of-obesity.

5. Akinbami LJ, Fryar CD. Current Asthma Prevalence by Weight Status Among Adults: United States, 2001-2014. NCHS Data Brief. 2016.

6. Lang JE, Bunnell HT, Hossain MJ, Wysocki T, Lima JJ, Finkel TH, et al. Being Overweight or Obese and the Development of Asthma. Pediatrics. 2018;142(6).

7. https://www.cdc.gov/coronavirus/2019-ncov/need-extra-precautions/ people-with-medical-conditions.html.

8. Mihălțan F. Managementul pacientului obez cu boli obstructive cronice. Medicina internă. 2014.

9. Koebnick C, Fischer H, Daley MF, et al. Interacting effects of obesity, race, ethnicity and sex on the incidence and control of adult-onset asthma. Allergy Asthma Clin Immunol. 2016; 12:50.

10. Contreras ZA, Chen Z, Roumeliotaki T, Annesi-Maesano I, Baïz N, von Berg $A$, et al.Bergström $A$, Does early onset asthma increase childhood obesity risk? A pooled analysis of 16 European cohorts. Eur Respir J. 2018;52(3).
Pacienții cu astm au un risc crescut de boală pneumococică - vaccinarea antipneumococică este recomandată pacienților ce asociază obezitate și astm [27].

\section{CONCLUZII}

Probabilitatea apariţiei astmului crește proporțional cu creșterea indicelui de masă corporală și a circumferinței taliei. Relația dintre cele două afecțiuni, deși demonstrată statistic, rămâne încă neclară în ceea ce privește mecanismul ei, deoarece există diverși alți factori care ar putea reprezenta „veriga de legătură“ în acest sistem complex. Unii dintre acești factori sunt implicaţi în creșterea severităţii formelor de infecție cu SARS-CoV-2. Identificarea precoce a contribuţiei obezităţii la manifestările de astm reprezintă o etapă important din anamneza și examenul clinic efectuat de către medical de familie acestor pacienți. Managementul acestei asocieri, până acum, este similar cu cel al pacienților normoponderali. Încurajarea strategiilor de scădere ponderală, prin modificarea stilului de viaţă, o dietă echilibrată, combaterea sedentarismului, este o etapă esențială a managementului astmului în practica medicului de familie. Este nevoie de studii suplimentare pentru a completa strategia de abordare a asocierii obezitate - astm - infecție SARS-CoV-2.

Conflict of interest: none declared Financial support: none declared

11. Holguin F, Bleecker ER, Busse WW, Calhoun WJ, Castro M, Erzurum SC,et al. Obesity and asthma: an association modified by age of asthma onset. J Allergy Clin Immunol. 2011;127(6):1486.

12. Dixon AE, Poynter ME. Mechanisms of Asthma in Obesity. Pleiotropic Aspects of Obesity Produce Distinct Asthma Phenotypes. Am J Respir Cell Mol Biol. 2016;54:601.

13. Hallstrand TS, Fischer ME, Wurfel MM, et al. Genetic pleiotropy between asthma and obesity in a community-based sample of twins. J Allergy Clin Immunol. 2005;116:1235.

14. Dhana K, Haines J, Liu G, et al. Association between maternal adherence to healthy lifestyle practices and risk of obesity in offspring: Results from two prospective cohort studies of mother-child pairs in the United States. BMJ 2018;362:k2486.

15. Polverino F. Cigarette Smoking and COVID-19: A Complex Interaction. Am J Respir crit Care Med. 2020;202(3):471-472.

16. Brigham EP, Steffen LM, London SJ, et al. Diet Pattern and Respiratory Morbidity in the Atherosclerosis Risk in Communities Study. Ann Am Thorac Soc. 2018;15:675.

17. Wood LG, Garg ML, Gibson PG. A high-fat challenge increases airway inflammation and impairs bronchodilator recovery in asthma. J Allergy Clin Immunol. 2011;127:1133.

18. Jayawardena R. Balanced diet is a major casualty în COVID-19. Diabetes Metab Syndr. 2020;14(5):1085-1086. 
19. Mok CK, Ng YL, Ahidjo BA, et al. Calcitriol, the active form of vitamin D, is a promising candidate for COVID-19 prophylaxis. medRxiv. 2020 (published online June 22) (preprint).

20. Maffei M, Halaas J, Ravussin E, et al. Leptin levels in human and rodent: measurement of plasma leptin and ob RNA in obese and weight-reduced subjects. Nat Med. 1995;1:1155-61.

21. Shore SA, Fredberg JJ. Obesity, smooth muscle, and airway hyperresponsiveness. J Allergy Clin Immunol. 2005;115:925-7.

22. Grifoni E, Valoriani A, Cei F, Lamanna R, Grazia Gelli AM, Ciambotti B, et al. Interleukin- 6 as prognosticator in patients with COVID-19. $J$ Infect. 2020;81(3):452-482.

23. Zhang ZL, Hou YL, Li DT, Li FZ. Laboratory findings of COVID-19: a systematic review and meta-analysis. Scand J Clin Lab Investig. 2020:1-7.
24. Peters MC, McGrath KW, Hawkins GA, et al. Plasma interleukin-6 concentrations, metabolic dysfunction, and asthma severity: a cross-sectional analysis of two cohorts. Lancet Respir Med. 2016; 4:574.

25. Zhao K, Li R, Wu X, Zhao Y, Wang T, Zheng Z, et al. Clinical features în 52 patients with COVID-19 who have increased leukocyte count: a retrospective analysis. Eur J Clin Microbiolo Infect Dis. 2020;1-9.

26. Green WD, Beck MA. Obesity Impairs the Adaptive Immune Response to Influenza Virus. Ann Am Thorac Soc. 2017;14:S406.

27. Torres A, Blasi F, Dartois N, Akova M. Which individuals are at increased risk of pneumococcal disease and why? Impact of COPD, asthma, smoking, diabetes, and/or chronic heart disease on community-acquired pneumonia and invasive pneumococcal disease. Thorax 2015;70:984. 